\title{
16. PETROLOGY AND GEOCHEMISTRY OF NODULAR WEBSTERITE INCLUSIONS IN HARZBURGITE, HOLE 920D ${ }^{1}$
}

\author{
Pamela D. Kempton² and Christopher J. Stephens ${ }^{3}$
}

\begin{abstract}
Two nodular websterite inclusions (3-4 cm in diameter) were identified in the predominantly harzburgitic core in Hole 920D. These inclusions and a representative harzburgite from the same drill hole have been analyzed for their $\mathrm{Sr}-, \mathrm{Nd}-$, and $\mathrm{Pb}-$ isotope ratios along with major-element mineral compositions to better understand their origin and significance. Elevated $\mathrm{Sr}$ and $\mathrm{Pb}$-isotope ratios provide abundant evidence for seawater interaction; ${ }^{208} \mathrm{~Pb} /{ }^{204} \mathrm{~Pb}$ ratios are higher for a given ${ }^{206} \mathrm{~Pb} /{ }^{204} \mathrm{~Pb}$ than those of normal (i.e., away from plume/hotspot influences) mid-ocean ridge basalt (N-MORB) from the North Atlantic and are consistent with a model for alteration involving a component of pelagic sediment. In contrast, Nd isotopes are largely unaffected by alteration processes. The pyroxenes separated from the Site 920 peridotites have higher ${ }^{143} \mathrm{Nd} /{ }^{144} \mathrm{Nd}$ ratios than most North Atlantic N-MORB, and higher than any measured abyssal peridotite to date. Nodular websterites have slightly higher Nd-isotope ratios than the analyzed harzburgite. Both websterites and harzburgite are isotopically distinct from all magmatic rocks in the Mid-Atlantic Ridge south of the Kane Fracture Zone (MARK) area, including gabbros, diabase dikes, and recent basalts. Thus, in terms of their isotopic compositions, the analyzed peridotites are not representative of the mantle source of the MARK magmatic rocks. High aluminum, iron, and titanium contents in the websterite pyroxenes suggest a vein origin, possibly as a result of decompression melting in an upwelling diapir. These veins preceded the more numerous clinopyroxenite veinlets and gabbroic dikes observed throughout the Site 920 core and probably formed in the asthenosphere. These inclusions may thus be analogous to Type I/Type I composite relationships found in alpine peridotites and alkali-basalt hosted xenolith suites. They provide evidence that interaction between basaltic melts and peridotite residues is a common and varied occurrence in the genesis of oceanic lithosphere.
\end{abstract}

\section{INTRODUCTION}

Studies of mantle-derived ultramafic xenoliths and peridotite massifs have highlighted the significance of magmatic veins in modifying the composition of the mantle. In particular, it is now commonly accepted that vein emplacement constitutes one of the most effective ways of refertilizing mantle previously depleted by partial melting processes. Conversely, the veins also provide information on the mechanisms of melt segregation and migration in the mantle, and may be physical evidence for the commonly postulated polybaric melting scenarios proposed to explain the compositions of primary mantle melts (MacKenzie, 1984; Klein and Langmuir, 1987; Salters and Hart, 1989; Langmuir et al., 1992).

Numerous studies of peridotite xenoliths in alkalic basalts, as well as alpine peridotite massifs, have indicated that such veins are variable in composition, ranging from $\mathrm{Fe}-\mathrm{Ti}-\mathrm{Al}$-rich assemblages of pyroxene \pm amphibole and mica (Type II) to $\mathrm{Mg}$ - $\mathrm{Cr}$-rich pyroxenites and websterites (Type I). Adapting the classification of Frey and Prinz (1978) for ultramafic xenoliths, Kempton (1987) referred to these different composite relationships as Type II/Type I and Type I/ Type I, depending on whether the vein was Type II or Type I in composition. Note that, in this classification, Type I compositions are characterized by high $\mathrm{Mg}$ and $\mathrm{Cr}$ contents and the clinopyroxene is typically $\mathrm{Cr}$ diopside. In contrast, Type II lithologies are characterized by $\mathrm{Fe}-, \mathrm{Al}-$, and Ti-rich compositions and are typified by the presence of $\mathrm{Al}$ augite \pm amphibole and/or phlogopite.

'Karson, J.A., Cannat, M., Miller, D.J., and Elthon, D. (Eds.), 1997. Proc. ODP, Sci. Results, 153: College Station, TX (Ocean Drilling Program).

${ }^{2}$ NERC Isotope Geosciences Laboratory, Kingsley Durham Centre, Keyworth, NG12 5GG, United Kingdom. P.KEMPTON@NIGL.NERC.AC.UK

${ }^{3}$ Department of Earth Sciences, The University of Queensland, Brisbane, 4072, Australia. (Present address: School of Geology, Queensland University of Technology, 2 George Street, Brisbane, 4000, Australia.)
In most composite samples, the vein minerals are compositionally distinct from the wallrock peridotite, and there is clear evidence that the assemblage represents the crystallization of magma in mantle conduits (Irving, 1980; Spray, 1989). Type I/Type I assemblages are more ambiguous in origin because the vein mineral phases are virtually indistinguishable in composition from those in the wallrock lherzolite or harzburgite; the veins are often only recognized by the concentration of green pyroxene in bands relative to the olivine-rich lherzolite or harzburgite. It has been argued that these may be either more ancient veins that later reequilibrated with the ambient mantle or veins that crystallized at greater depths in the mantle (Sinigoi et al., 1983; Kempton, 1987; Scribano, 1987). Alternatively, they may simply be metamorphic segregations of pyroxene (Dick and Sinton, 1979; Spray, 1989).

Abundant evidence for magmatic intrusion into depleted peridotite mantle is observed in the Leg 153 core at Site 920 . These range from $\mathrm{cm}$-wide gabbroic dikelets to $\mathrm{mm}$-wide clinopyroxenite veins. These rocks, and the chemical consequences of their interaction with the peridotite wallrock, are the subject of several studies in this volume (Casey, this volume; Stephens, this volume; Niida, this volume; Cannat, Chatin, et al., this volume). The gabbroic dikelets are probably most directly analogous to the Type II/Type I composite relationships observed in basalt-hosted ultramafic xenoliths.

Two nodular concentrations of pyroxene that may be analogous to Type I/Type I composite relationships were also identified in Hole $920 \mathrm{D}$. These websterite inclusions are the subject of this paper. Although websterites are extremely rare among abyssal peridotites, they are not unknown. Dick et al. (1984) reported the mineral modes of two websterite samples recovered by dredging, one from the Kane Fracture Zone and one from the Islas Orcadas Fracture Zone. A websterite sample was also recovered during drilling on Leg 109 at Site 670 , just $20 \mathrm{~km}$ south of Site 920 . Major-element mineral chemistry as well as modal information are available for this sample (Fujii, 1990; Juteau et al., 1990). More recently, the petrography and major- 
element mineral chemistry of three clinopyroxenites from the Tereveka transform fault (located on the western rift of the Easter microplate) have been described by Constantin et al. (1995). We have analyzed the Site 920 websterites for $\mathrm{Sr}, \mathrm{Nd}$, and $\mathrm{Pb}$ isotopes along with major-element mineral compositions to characterize these unusual features. Our new data will be discussed in conjunction with the data on $\mathrm{Cr}$ diopside websterites and clinopyroxenites from other localities to further our understanding of the origin and significance of these rare lithologies.

\section{SAMPLE DESCRIPTION}

Two pyroxene-rich nodular inclusions were observed in the Leg 153 core (Samples 153-920D-13R-2, 65-68 cm, and 15R-3, 18-21 $\mathrm{cm})$. Section 153-920D-13R-2 consists predominantly of porphyroclastic serpentinized harzburgite to dunite. Modal proportions of the harzburgite are variable: olivine ranges from $75 \%$ to $98 \%$, orthopyroxene from $2 \%$ to $23 \%$, and clinopyroxene from $0 \%$ to $1 \%$. Spinel occurs in abundances of less than $1 \%$ throughout. Total alteration (principally serpentinization) of the harzburgite is high, and it increases with decreasing pyroxene content from $70 \%$ to greater than $95 \%$ of the rock. Piece 2 in Section 13R-2 contains an oval-shaped ( 3 $\times 4 \mathrm{~cm}$ ) inclusion or band of olivine websterite. Contacts with the surrounding harzburgite are sharp and smooth. In contrast to the rest of the core, the inclusion consists of $57 \%$ orthopyroxene, $30 \%$ clinopyroxene, $10 \%$ olivine, and $3 \%$ spinel; opaque minerals occur in trace amounts. The pyroxenes are also significantly more coarse grained than the pyroxenes typically found in the lherzolites and harzburgites. Alteration of the inclusion is significantly less than that of the surrounding harzburgite, although the olivine in the websterite is partially altered to serpentine in a mesh texture analogous to that seen in the surrounding harzburgite. The shipboard assessment of the inclusion is that "it may either be a xenolith or a vein" (Shipboard Scientific Party, 1995).

Similar to that of Section 13R-2, a pyroxene-rich nodular inclusion occurs in Piece 2 of Section 153-920D-15R-3. This section is also predominantly serpentinized porphyroclastic harzburgite. However, the clinopyroxene content may be slightly higher than it is in Section 13R-2. Visual estimates from the core suggest that, on average, the harzburgite in this section consists of $80 \%$ olivine, $14 \%$ orthopyroxene, $5 \%$ clinopyroxene, and less than $1 \%$ spinel. In general, alteration of Section 15R-3 is also slightly less than that of Section $13 \mathrm{R}-2$, averaging about $60 \%$ throughout. However, petrographic description of a thin section taken approximately $20 \mathrm{~cm}$ below the websterite nodule indicates that in this interval the rock originally consisted of $80 \%-87 \%$ olivine, $10 \%-17 \%$ orthopyroxene, $<2 \%$ clinopyroxene and $<1 \%$ spinel; this interval is also more than $95 \%$ altered to serpentine, chlorite, talc, and/or tremolite. Modal proportions of the websterite inclusion were not noted during the shipboard core description, but shore-based analysis indicates than this nodule is more clinopyroxene rich than the websterite in Section 13R-2, with clinopyroxene approximately twice as abundant as orthopyroxene. Similar to the nodular inclusion in Section 13R-2, the pyroxenes are significantly more coarse grained than pyroxenes found in the lherzolites and harzburgites elsewhere in the core. The contact between the websterite and harzburgite in this section is complicated by the presence of a 6- to 8-mm-wide band of altered pyroxene adjacent to the websterite. A second trail of secondary pyroxene crystals branches from this vein and runs along the length of Piece 2. These trails are oblique to the foliation and are interpreted as magmatic veins (Shipboard Scientific Party, 1995). They are clearly later in origin than the nodular inclusion.

Pyroxenes from the nodular websterites in Sections 13R-2 and $15 \mathrm{R}-3$ are similar petrographically to the pyroxenes that occur in lherzolites and harzburgites throughout the core at Site 920 (Stephens, this volume). In particular, they contain exsolution lamellae of pyroxene, consistent with low-temperature re-equilibration, and similar structural characteristics (e.g., kink-banding and recrystallization of porphyroclasts).

The modal proportions of mineral phases in the websterites from Section 13R-2 are similar to those in other abyssal websterites (Table 1). In particular, clinopyroxene is typically less than or equal to orthopyroxene in modal abundance. However, note that the modal mineralogies of adjacent samples of the websterite from Site 670 differ significantly. In one sample, orthopyroxene and clinopyroxene occur in roughly equal amounts (Juteau et al., 1990); in the other, orthopyroxene is three times more abundant than clinopyroxene (Fujii, 1990). This highlights the problem of determining accurate modes for these samples because they tend to be both small in size and coarse grained. The websterite from Section 15R-3 is more clinopyroxene rich than most reported websterites, but nonetheless contains significant amounts of orthopyroxene. In contrast to the websterites, clinopyroxenites from the Tereveka transform consist of greater than 90\% clinopyroxene, with only minor enstatite (Constantin et al., 1995).

Contacts between websterite and harzburgite were not described for the sample from Site 670 , but the websterites dredged from the Kane and Islas Orcadas Fracture Zones are described as occurring in bands (Dick et al., 1984). Similarly, two of the clinopyroxenites from Tereveka (Constantin et al., 1995) are described as veins, one occurring as a layer subparallel to foliation, the other recording a complex sequence of multiple melt injections with mineral assemblages ranging from $\mathrm{Cr}$ diopside at the vein margins to gabbroic in the core. A third clinopyroxenite bears some physical similarities with the Site 920 websterites in that it is described as a "cluster" $2 \mathrm{~cm}$ in diameter, enclosed in harzburgite (Constantin et al., 1995). The cluster is $>90 \%$ clinopyroxene with fine-grained interstitial orthopyroxene + spinel \pm olivine. The contact with the harzburgite is described as sharp. Analogous to the Site 920 websterites, all of the clinopyroxenites and websterites described above are significantly less altered (i.e., less serpentinized) than the surrounding harzburgites.

In addition to the websterite inclusions, a sample of more typical peridotite from Site 920 was analyzed for comparative purposes. Sample 153-920D-22R-7, 45-49 cm, was taken from one of the more clinopyroxene-rich intervals of the core where the assemblage is borderline lherzolite/harzburgite, containing $4 \%-5 \%$ clinopyroxene, $15 \%-17 \%$ orthopyroxene, and $81 \%-83 \%$ olivine. The harzburgite exhibits an elongate porphyroclastic texture typical of the Site 920 core. The section is $80 \%-90 \%$ altered to serpentine.

Approximately $50 \mathrm{~cm}$ below the harzburgite sample analyzed in this study, a 1-cm-wide metagabbro vein crosscuts the peridotite. Iso-

Table 1. Modal analyses of olivine websterites.

\begin{tabular}{lcccc}
\hline \multicolumn{1}{c}{ Sample } & Olivine & Orthopyroxene & Clinopyroxene & Spinel \\
\hline 153-920D-13R-2, 65-68 cm (this study) & 10 & 57 & 30 & 3 \\
109-670A-9R-1, 19-20 cm (1) & 12 & 42.2 & 45.7 & 0.1 \\
109-670A-9R-1, 22-24 cm (2) & 20 & 60 & 20 & 1 \\
AII 96-1-3 (Kane FZ) (3) & 20.8 & 43.1 & 34.3 & 1.8 \\
1011/76-60-52 (Islas Orcadas FZ) (3) & 28.8 & 53.2 & 17.3 & 0.7 \\
\hline
\end{tabular}

Notes: Data from (1) Fujii (1990), (2) Juteau et al. (1990), (3) Dick et al. (1984). FZ = Fracture Zone. 
topic analyses of these metagabbro veins is the subject of a separate study (Kempton and Hunter, this volume). Here, however, we include a high-temperature brown amphibole (Sample 153-920D-12R$1,128-134 \mathrm{~cm}$ ) separated from a vein that crosscuts the peridotite and is oblique to the high-temperature crystal-plastic foliation. Visual core descriptions (Shipboard Scientific Party, 1995) indicate that the vein was originally in excess of $5 \mathrm{~cm}$ thick. The vein is composed of three distinct bands: a zone (15-20 mm wide) of brown amphibole, chlorite, zeolite, and clay minerals, bounded by a band (10-15 mm wide) of chlorite and serpentine, which in turn abuts a white band of tremolite. It is unclear whether the vein was originally magmatic hornblende or a pyroxenite/gabbro that was subsequently replaced, first by hornblende, and later by lower-temperature alteration phases (e.g., tremolite and chlorite). Several small altered magmatic veins are observed elsewhere in the core, but these do not contain hornblende.

\section{ANALYTICAL TECHNIQUES}

Mineral separates for isotopic analyses of strontium, neodymium, and lead were hand-picked from crushed and sieved splits of the whole-rock sample. Because of the small size of the nodular websterites, orthopyroxene and clinopyroxene were combined for analysis. For Sample 153-920D-15R-3, 18-21 cm, the analyzed split contained approximately $80 \%$ clinopyroxene and $20 \%$ orthopyroxene: for Sample 13R-2, 65-68 cm, the analyzed split was approximately $45 \%$ clinopyroxene and $55 \%$ orthopyroxene. In addition, serpentine separated from Sample 15R-3, 18-21 cm, was analyzed to determine the effect of alteration/serpentinization on the peridotites. It was possible to separate sufficient quantities of both clinopyroxene and orthopyroxene from the harzburgite in Section 22R-7 so these phases were analyzed separately for this sample. The brown amphibole is from an altered vein, and we separated the white alteration phase(s) to investigate this form of alteration; the material analyzed is predominantly tremolite.

The mineral separates were cleaned ultrasonically in Milli- $Q$ brand $\mathrm{H}_{2} \mathrm{O}$ to remove surface contaminants acquired through drilling or handling. They were then hand-picked in methanol using a binocular microscope to ensure the highest purity possible for each sample. Note that the silicate phases in Sample 153-902D-13R-2, 65-68 cm, contained abundant tiny opaque inclusions that could not be entirely eliminated. This precluded separation of a totally pure pyroxene mineral separate. We therefore analyzed two splits of this sample-one with opaque inclusions and a high-graded split in which inclusions were avoided as much as possible. We estimate that this latter split contained $<1 \%$ inclusions. Except for the serpentine and the white alteration phase(s) separated from the amphibole vein, all samples were leached prior to dissolution in $6-\mathrm{M} \mathrm{HCl}$ on a hot plate at $\sim 100^{\circ} \mathrm{C}$ for $\sim 30 \mathrm{~min}$. The leachates were removed and the mineral grains rinsed in Milli-Q $\mathrm{H}_{2} \mathrm{O}$. The leachates and the Milli-Q $\mathrm{H}_{2} \mathrm{O}$ rinses were combined and processed for isotopic analysis along with the cleaned mineral separates. The samples were then crushed in an agate mortar.

Because the concentrations of $\mathrm{Pb}, \mathrm{Sr}$, and $\mathrm{Nd}$ are so low, relatively large sample sizes (250-650 mg) were used where possible. For total sample sizes greater than $250 \mathrm{mg}$, dissolutions were performed on multiple splits of the same sample, with each split not exceeding 250 $\mathrm{mg}$. Further details of the geochemical procedures used are given in Kempton and Hunter (this volume). $\mathrm{Sr}, \mathrm{Nd}$, and $\mathrm{Pb}$ were run as the metal species on single $\mathrm{Ta}$, double $\mathrm{Re}+\mathrm{Ta}$, and single Re filaments, respectively, using a Finnegan MAT 262 multicollector mass spectrometer in static mode at the NERC Isotope Geosciences Laboratory (NIGL). Blanks for $\mathrm{Sr}, \mathrm{Nd}$, and $\mathrm{Pb}$ are typically less than $400 \mathrm{pg}, 300$ $\mathrm{pg}$, and $200 \mathrm{pg}$, respectively. However, a Nd blank of $2.6 \mathrm{ng}$ was measured for one batch of samples. Nevertheless, the ${ }^{143} \mathrm{Nd} /{ }^{144} \mathrm{Nd}$ of most blanks is lower than the sample values measured here, and we believe it is unlikely that there has been a serious effect on our sample data. Reference standards throughout the course of analysis averaged values of ${ }^{87} \mathrm{Sr} /{ }^{86} \mathrm{Sr}=0.710184 \pm 14$ for the NBS987 standard, and ${ }^{143} \mathrm{Nd} /{ }^{144} \mathrm{Nd}=0.511106 \pm 10$ for the Johnson Matthey $(\mathrm{J} \& \mathrm{M}) \mathrm{Nd}$ standard. ${ }^{87} \mathrm{Sr} /{ }^{86} \mathrm{Sr}$ was normalized to ${ }^{86} \mathrm{Sr} /{ }^{88} \mathrm{Sr}=0.1194 ;{ }^{143} \mathrm{Nd} /{ }^{144} \mathrm{Nd}$ was normalized to a value of ${ }^{146} \mathrm{Nd} /{ }^{144} \mathrm{Nd}=0.7219$. Samples for this and related studies were analyzed over a period of 18 months; to minimize the effects of machine drift, sample results are further normalized to accepted values for NBS 987 and J\&M of 0.71024 and 0.51111 , respectively. Minimum uncertainties are derived from external precision of standard measurements, and these average $27 \mathrm{ppm}$ for ${ }^{143} \mathrm{Nd} /{ }^{144} \mathrm{Nd}$ and $18 \mathrm{ppm}$ for ${ }^{87} \mathrm{Sr} /{ }^{86} \mathrm{Sr}$. Based on repeated runs of NBS981 common $\mathrm{Pb}$ standard, the reproducibility is better than $\pm 0.1 \%$ per a.m.u. $\mathrm{Pb}$-isotopic ratios were corrected relative to the average standard $\mathrm{Pb}$-isotopic compositions of Todt et al. (1984). The $\mathrm{Pb}$-isotope analyses were particularly difficult to perform, and beam currents were often less than $1 \mathrm{pA}$ on ${ }^{208} \mathrm{~Pb}$; this means that the ${ }^{204} \mathrm{~Pb}$ intensity is typically $<0.03 \mathrm{pA}$. This low intensity on ${ }^{204} \mathrm{~Pb}$ adds considerably to the uncertainty of the $\mathrm{Pb}$-isotope ratios involving this isotope, and it is particularly apparent on diagrams involving ${ }^{207} \mathrm{~Pb} /$ ${ }^{204} \mathrm{~Pb}$ because the range is already very small for this ratio. Errors quoted for samples are one standard deviation from measured or calculated values.

Major-element mineral analyses were performed at the University of Queensland. Details of analytical techniques can be found in Stephens (this volume).

\section{RESULTS Major-Element Mineral Chemistry}

Average compositions of the four primary mineral phases present in the two nodular inclusions are presented in Table 2. Although there is no statistically significant chemical zonation evident within the individual grains of the websterites, the presence of exsolution complicates interpretation of the major-element mineral analyses because much of it is on a micron scale. Therefore, average compositions have been calculated from multiple broad beam analyses (Table 2). Pyroxenes from the websterites are similar in their major components ( $\mathrm{Ca}-\mathrm{Mg}-\mathrm{Fe}$ ), both to each other and to Site 920 peridotite pyroxenes (Fig. 1). Pyroxene from the websterite in Section 15R-3 is, nonetheless, slightly more Fe rich and has a lower $\mathrm{Mg} \#$ (i.e., $100 \cdot \mathrm{Mg} / \mathrm{Mg}+$ $\mathrm{Fe}^{2+}$ ) than the average for Site 920 peridotites (Table 2). Olivine compositions from the websterites, however, are similar to average Site 920 peridotite. Fujii (1990) and Juteau et al. (1990) noted a similar overlap in olivine and pyroxene compositions between the Site 670 websterite and associated harzburgites.

However, differences in minor-element concentrations mirror the small differences in major mineral components of the pyroxenes from Sample 15R-3, 18-21 cm. In particular, pyroxenes from Sample $15 \mathrm{R}-3,18-21 \mathrm{~cm}$, have higher $\mathrm{TiO}_{2}$ and $\mathrm{Na}_{2} \mathrm{O}$ contents (Table 2), and pyroxenes from both websterite samples have higher $\mathrm{Cr}_{2} \mathrm{O}_{3}$ for a given $\mathrm{Al}_{2} \mathrm{O}_{3}$ content compared with other Site 920 peridotites (Fig. 2). Relative to other peridotites from or near the Mid-Atlantic Ridge, south of the Kane Fracture Zone (MARK) area (i.e., Sites 670 and 395 ), the Site 920 pyroxenes have intermediate $\mathrm{Al}_{2} \mathrm{O}_{3}$ contents, but the range of $\mathrm{Cr}_{2} \mathrm{O}_{3}$ is similar for each site. Recall that Site 670 is located only about $18 \mathrm{~km}$ south of Site 920 and is also from the rift valley wall, so it is presumably of a similar age and has a similar petrogenetic history to peridotites from Site 920 . Peridotites from Site 395 are located approximately $100 \mathrm{~km}$ west of Site 670 in 7-m.y.-old crust. Also shown for comparison are the highly depleted pyroxenes from peridotites dredged along the Mid-Atlantic Ridge at $43^{\circ} \mathrm{N}$ (Shibata and Thompson, 1986) and harzburgites from the Tereveka transform (Constantin et al., 1995). The extremely low Al contents of peridotites from $43^{\circ} \mathrm{N}$ are interpreted as evidence of extensive depletion as a result of partial melting processes, possibly melting beyond the 
Table 2. Average compositions of primary phases in Site 920 websterites.

\begin{tabular}{|c|c|c|c|c|c|c|c|c|c|c|}
\hline & \multicolumn{5}{|c|}{ Clinopyroxene } & \multicolumn{5}{|c|}{ Orthopyroxene } \\
\hline & \multicolumn{2}{|c|}{$13 \mathrm{R}-2,65-68 \mathrm{~cm}$} & \multicolumn{2}{|c|}{$15 \mathrm{R}-3,18-21 \mathrm{~cm}$} & \multirow{2}{*}{$\begin{array}{l}\text { Site } 920 \\
n=365\end{array}$} & \multicolumn{2}{|c|}{$13 \mathrm{R}-2,65-68 \mathrm{~cm}$} & \multicolumn{2}{|c|}{$15 \mathrm{R}-3,18-21 \mathrm{~cm}$} & \multirow{2}{*}{$\begin{array}{l}\text { Site } 920 \\
n=282\end{array}$} \\
\hline & $n=54$ & s.d. & $n=41$ & s.d. & & $n=37$ & s.d. & $n=23$ & s.d. & \\
\hline $\begin{array}{l}\mathrm{SiO}_{2} \\
\mathrm{TiO}_{2} \\
\mathrm{Al}_{2} \mathrm{O}_{3} \\
\mathrm{Cr}_{2} \mathrm{O}_{3} \\
\mathrm{FeO} \mathrm{MnO} \\
\mathrm{NiO} \\
\mathrm{MgO} \\
\mathrm{CaO} \\
\mathrm{Na}_{2} \mathrm{O} \\
\mathrm{K}_{2} \mathrm{O}\end{array}$ & $\begin{array}{r}51.25 \\
0.11 \\
4.83 \\
1.19 \\
2.38 \\
0.08 \\
0.05 \\
16.37 \\
23.68 \\
0.04 \\
0.01\end{array}$ & $\begin{array}{l}0.83 \\
0.03 \\
0.63 \\
0.19 \\
0.21 \\
0.02 \\
0.03 \\
0.73 \\
1.07 \\
0.03 \\
0.01\end{array}$ & $\begin{array}{r}50.99 \\
0.14 \\
5.05 \\
1.37 \\
2.84 \\
0.10 \\
0.05 \\
16.63 \\
22.29 \\
0.10 \\
0.00\end{array}$ & $\begin{array}{l}0.51 \\
0.03 \\
0.23 \\
0.08 \\
0.26 \\
0.02 \\
0.03 \\
0.79 \\
1.25 \\
0.04 \\
0.01\end{array}$ & $\begin{array}{r}51.77 \\
0.11 \\
4.72 \\
1.12 \\
2.52 \\
0.09 \\
0.05 \\
16.75 \\
22.87 \\
0.09 \\
0.01\end{array}$ & $\begin{array}{r}55.36 \\
0.04 \\
3.82 \\
0.76 \\
6.10 \\
0.14 \\
0.09 \\
32.88 \\
1.10 \\
0.01 \\
0.01\end{array}$ & $\begin{array}{l}0.68 \\
0.02 \\
0.49 \\
0.16 \\
0.22 \\
0.02 \\
0.03 \\
0.67 \\
0.52 \\
0.01 \\
0.01\end{array}$ & $\begin{array}{r}55.27 \\
0.07 \\
3.86 \\
0.92 \\
6.00 \\
0.14 \\
0.11 \\
32.28 \\
1.79 \\
0.01 \\
0.01\end{array}$ & $\begin{array}{l}0.46 \\
0.02 \\
0.23 \\
0.06 \\
0.16 \\
0.02 \\
0.03 \\
0.60 \\
0.47 \\
0.01 \\
0.01\end{array}$ & $\begin{array}{r}55.13 \\
0.04 \\
4.11 \\
0.82 \\
5.96 \\
0.14 \\
0.10 \\
32.64 \\
1.48 \\
0.01 \\
0.01\end{array}$ \\
\hline \multirow[t]{4}{*}{$\mathrm{Mg} \#$} & 92.5 & & 91.3 & & 92.3 & 90.7 & & 90.6 & & 90.8 \\
\hline & \multicolumn{5}{|c|}{ Olivine } & \multicolumn{5}{|c|}{ Spinel } \\
\hline & \multicolumn{2}{|c|}{$13 \mathrm{R}-2,65-68 \mathrm{~cm}$} & \multicolumn{2}{|c|}{$15 \mathrm{R}-3,18-21 \mathrm{~cm}$} & Site 920 & \multicolumn{2}{|c|}{$13 \mathrm{R}-2,65-68 \mathrm{~cm}$} & \multicolumn{2}{|c|}{$15 \mathrm{R}-3,18-21 \mathrm{~cm}$} & Site 920 \\
\hline & $n=22$ & s.d. & $n=8$ & s.d. & $n=346$ & $n=15$ & s.d. & $n=7$ & s.d. & $n=364$ \\
\hline $\begin{array}{l}\mathrm{SiO}_{2} \\
\mathrm{TiO}_{2} \\
\mathrm{Al}_{2} \mathrm{O}_{3} \\
\mathrm{Cr}_{2} \mathrm{O}_{3} \\
\mathrm{FeO} \\
\mathrm{MnO} \\
\mathrm{NiO} \\
\mathrm{MgO} \\
\mathrm{CaO} \\
\mathrm{Na}_{2} \mathrm{O} \\
\mathrm{K}_{2} \mathrm{O}\end{array}$ & $\begin{array}{r}41.33 \\
0.01 \\
0.01 \\
0.01 \\
9.23 \\
0.14 \\
0.39 \\
49.80 \\
0.03 \\
0.01 \\
0.01\end{array}$ & $\begin{array}{l}0.32 \\
0.01 \\
0.01 \\
0.02 \\
0.19 \\
0.02 \\
0.04 \\
0.65 \\
0.01 \\
0.01 \\
0.01\end{array}$ & $\begin{array}{r}41.22 \\
0.02 \\
0.02 \\
0.02 \\
9.28 \\
0.13 \\
0.37 \\
50.04 \\
0.04 \\
0.00 \\
0.00\end{array}$ & $\begin{array}{l}0.52 \\
0.02 \\
0.01 \\
0.01 \\
0.20 \\
0.02 \\
0.02 \\
0.55 \\
0.02 \\
0.01 \\
0.00\end{array}$ & $\begin{array}{r}41.16 \\
0.01 \\
0.01 \\
0.01 \\
9.15 \\
0.13 \\
0.38 \\
50.08 \\
0.04 \\
0.01 \\
0.01\end{array}$ & $\begin{array}{r}0.02 \\
0.05 \\
43.70 \\
24.13 \\
13.30 \\
0.16 \\
0.23 \\
17.49 \\
0.02 \\
0.01 \\
0.01\end{array}$ & $\begin{array}{l}0.01 \\
0.02 \\
0.90 \\
0.49 \\
0.21 \\
0.03 \\
0.03 \\
0.28 \\
0.01 \\
0.01 \\
0.01\end{array}$ & $\begin{array}{r}0.03 \\
0.07 \\
41.37 \\
26.22 \\
13.73 \\
0.16 \\
0.22 \\
17.06 \\
0.04 \\
0.02 \\
0.01\end{array}$ & $\begin{array}{l}0.01 \\
0.02 \\
1.31 \\
0.52 \\
0.29 \\
0.02 \\
0.04 \\
0.34 \\
0.01 \\
0.02 \\
0.01\end{array}$ & $\begin{array}{r}0.04 \\
0.07 \\
42.45 \\
25.75 \\
14.04 \\
0.17 \\
0.20 \\
16.91 \\
0.01 \\
0.01 \\
0.00\end{array}$ \\
\hline $\begin{array}{l}\mathrm{Mg \#} \\
\mathrm{Cr} \#\end{array}$ & 90.7 & & 90.7 & & 90.8 & $\begin{array}{l}70.3 \\
27.0\end{array}$ & & $\begin{array}{l}69.1 \\
29.8\end{array}$ & & $\begin{array}{l}68.4 \\
28.9\end{array}$ \\
\hline
\end{tabular}

Notes: $n=$ the number of analyses used to calculate the average. The standard deviation (s.d.) quoted is $1 \sigma . \mathrm{Mg} \#$ calculated on the basis of cation proportions as $\mathrm{Mg} /\left(\mathrm{Mg}+\mathrm{Fe}{ }^{+2}\right) \cdot 100$; $\mathrm{Cr} \#$ calculated as $\mathrm{Cr} /(\mathrm{Cr}+\mathrm{Al}) \cdot 100$. Averages for Site 920 are from Stephens (this volume).

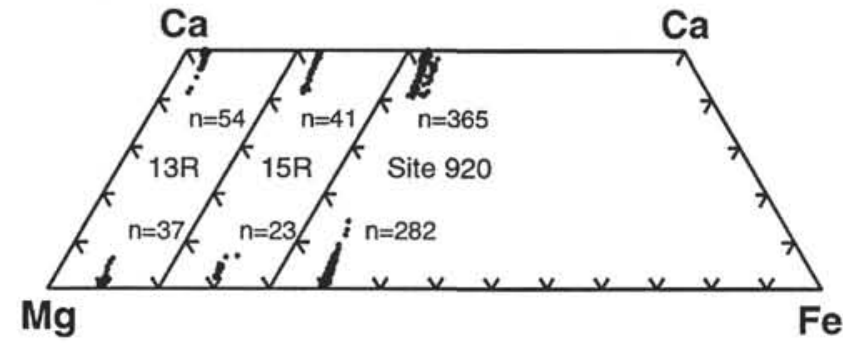

Figure 1. Compositions of pyroxene from websterite nodules in Sections 153-920D-13R-2 and 15R-3 shown in a pyroxene quadrilateral and compared with the total range of pyroxene compositions for Site 920 (Stephens, this volume).

diopside-out equilibria (Hess, 1992); this high degree of partial melting has been attributed to the proximity of the Azores hotspot. In contrast to the websterites from Site 920, the websterite from Site 670 has a lower $\mathrm{Cr}_{2} \mathrm{O}_{3}$ concentration for a given $\mathrm{Al}_{2} \mathrm{O}_{3}$, not only relative to the Site 920 peridotites, but also to the Site 670 harzburgites. Clinopyroxenites from Tereveka have both higher and lower $\mathrm{Cr}_{2} \mathrm{O}_{3}$ contents relative to Tereveka harzburgites, but the clinopyroxenite cluster has the highest $\mathrm{Al}_{2} \mathrm{O}_{3}$ of the Tereveka $\mathrm{Cr}$ diopsides. Constantin et al. (1995) also note that the Tereveka clinopyroxenites have high $\mathrm{TiO}_{2}$ contents relative to most harzburgites from the same area.

Although both spinels from Site 920 websterites fall within the total range for Site 920 peridotites (see Stephens, this volume), spinel in Sample 15R-3, 18-21 cm, is one of the most $\mathrm{Cr}$ rich of the suite (Fig. 3; Table 2). Analogous to the pyroxene results, spinel in the Site 670 websterite has low $\mathrm{Cr} \#$ (i.e., $100 \cdot \mathrm{Cr} / \mathrm{Cr}+\mathrm{Al}$ ) for a given $\mathrm{Mg \#}$ relative to the associated harzburgites. In contrast, abyssal peridotites from Mid-Atlantic Ridge $43^{\circ} \mathrm{N}$ and Tereveka have the highest $\mathrm{Cr}$ numbers and extend to the lowest $\mathrm{Mg}$ numbers. Site 920 peridotite

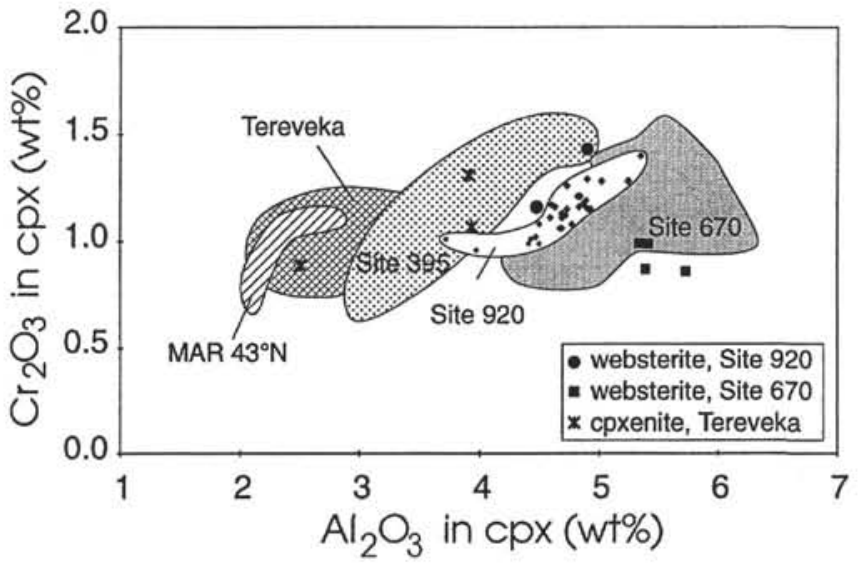

Figure 2. $\mathrm{Cr}_{2} \mathrm{O}_{3}$ vs. $\mathrm{Al}_{2} \mathrm{O}_{3}$ (wt\%) in clinopyroxene (cpx) from websterite Samples 153-920D-13R-2, 65-68 cm, and 15R-3, 18-21 cm. Shown for comparison are data for websterites from Site 670 (Fujii, 1990; Juteau et al., 1990) and clinopyroxenites (cpxenite) from the Tereveka transform (Constantin et al., 1995). Also shown are fields for harzburgite clinopyroxenes from Site 920 (Stephens, this volume), Site 670 (Fujii, 1990; Juteau et al., 1990; Komor et al., 1990; Hébert et al., 1990), Site 395 (Fujii, 1990), MidAtlantic Ridge (MAR) $43^{\circ} \mathrm{N}$ (Shibata and Thompson, 1986), and the Tereveka transform (Constantin et al., 1995).

spinels are intermediate in composition between those from Sites 670 and 395. Spinels from Tereveka clinopyroxenites have both lower and higher $\mathrm{Cr}$ contents compared with spinels from Tereveka harzburgites. In general, increasing $\mathrm{Cr} \#$ in spinel reflects increasing degrees of partial melting in the mantle (Dick and Bullen, 1984). However, Dick (1989) also notes that whole-rock chromium contents in abyssal peridotites decrease rather than increase with proximity to 
the Bouvet hotspot, correlating inversely with the abundances of compatible elements magnesium and nickel. This suggests that chromium behaves incompatibly during mantle melting.

\section{Isotopes}

Results from isotopic analyses are summarized in Table 3 . Sr-and Nd-isotope data are shown in Figure 4 relative to fields for North Atlantic mid-ocean ridge basalt (MORB) and Leg 153 gabbros from Sites 920 to 924 . Also shown is the field for recent MARK basalts. In general, the $\mathrm{Sr}$-isotope compositions of the peridotite pyroxenes and brown amphibole are significantly higher than Leg 153 gabbros from Sites 920 to 924 and higher than North Atlantic MORB. The lowest ${ }^{87} \mathrm{Sr}{ }^{86} \mathrm{Sr}$ ratio occurs in the clinopyroxene separated from the harzburgite in Section 153-920D-22R-7. Some gabbro dikes from Site 920 have ${ }^{87} \mathrm{Sr} /{ }^{86} \mathrm{Sr}$ ratios that overlap the low end of the peridotite range. The high-temperature brown amphibole has a similar isotopic composition to that of the clinopyroxene from the harzburgite in Section 22R-7. In contrast, the split of the websterite from Section 13R2 that contains abundant inclusions has the highest $\mathrm{Sr}$-isotope ratios of the peridotites. The high-graded split of this sample and the websterite from Section $15 \mathrm{R}-3$ have intermediate ${ }^{87} \mathrm{Sr} /{ }^{86} \mathrm{Sr}$ ratios, but $\mathrm{Nd}$ isotope compositions are indistinguishable within analytical error.

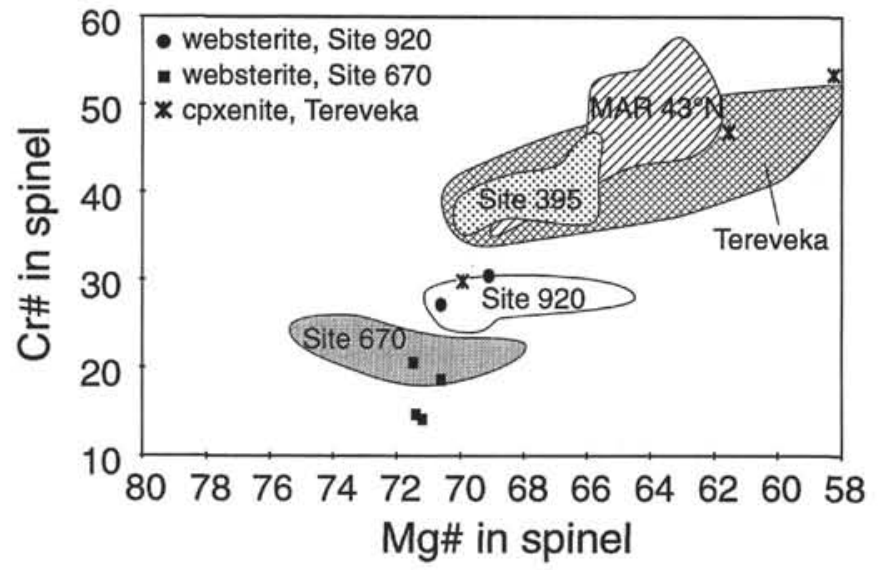

Figure 3. Mg\# vs. Cr\# for spinels from websterite Samples 153-920D-13R-2, $65-68 \mathrm{~cm}$, and $15 \mathrm{R}-3,18-21 \mathrm{~cm}$. Shown for comparison are data for spinels in websterites from Site 670 and in clinopyroxenites (cpxenite) from Tereveka. Also shown are fields for harzburgite spinels from Site 920, Site 670, Site 395, Mid-Atlantic Ridge (MAR) $43^{\circ} \mathrm{N}$, and the Tereveka transform. Data sources and abbreviations as in Figure 2.
The serpentine and mineral leachates have the highest ${ }^{87} \mathrm{Sr} /{ }^{86} \mathrm{Sr}$ ratios measured for the sample set.

The ${ }^{143} \mathrm{Nd} /{ }^{144} \mathrm{Nd}$ ratios of the peridotites overlap the high end of the MORB field, but are higher than the values measured for the gabbros from Sites 920 to 924 . The Nd-isotope compositions of the secondary amphibole and the serpentine overlap those of the Leg 153 gabbros. Few leachates had sufficient Nd to analyze, but those that did indicate the leachable component has a relatively low ${ }^{143} \mathrm{Nd} /{ }^{144} \mathrm{Nd}$ value (Table 3).

$\mathrm{Pb}$-isotope results are shown in Figure 5. Similar to the $\mathrm{Sr}$-isotope results, the amphiboles and peridotite pyroxenes have more radiogenic $\mathrm{Pb}$-isotope values than the Leg 153 gabbros. Indeed, the peridotites have significantly higher ${ }^{206} \mathrm{~Pb} / 204 \mathrm{~Pb},{ }^{207} \mathrm{~Pb} / 204 \mathrm{~Pb}$, and ${ }^{208} \mathrm{~Pb} / 204 \mathrm{~Pb}$. The data are shown relative to the fields for North Atlantic MORB and Atlantic sediments, as well as the field for recent MARK basalts. The peridotites and secondary amphibole lie in the middle of the range of ${ }^{206} \mathrm{~Pb} / 204 \mathrm{~Pb}$ shown by MORB and on the low end of the range of Atlantic sediments. In ${ }^{208} \mathrm{~Pb} /{ }^{204} \mathrm{~Pb}$, they lie above and parallel to the field of Mid-Atlantic Ridge basalts, and overlap the field of Atlantic sediments at higher ${ }^{206} \mathrm{~Pb} /{ }^{04} \mathrm{~Pb}$, but have significantly higher ${ }^{207} \mathrm{~Pb} /{ }^{204} \mathrm{~Pb}$ than all MORB. The brown amphibole also has slightly higher ${ }^{207} \mathrm{~Pb} /$ ${ }^{204} \mathrm{~Pb}$ than MORB, although it lies within the field of MORB in ${ }^{208} \mathrm{~Pb} /$ ${ }^{204} \mathrm{~Pb}$ vs. ${ }^{206} \mathrm{~Pb} /{ }^{204} \mathrm{~Pb}$. Surprisingly, the serpentine separated from Sample $15 \mathrm{R}-3,18-21 \mathrm{~cm}$, has a $\mathrm{Pb}$-isotope composition more similar to the vein amphiboles than to the peridotites.

The leachates from the peridotite pyroxenes show a wide range of compositions. Most unusual are the relatively unradiogenic ${ }^{206} \mathrm{~Pb} /$ ${ }^{204} \mathrm{~Pb}$ values of the leachates from the harzburgite pyroxenes in Section $22 \mathrm{R}-7$; these leachates have significantly higher ${ }^{207} \mathrm{~Pb} /{ }^{204} \mathrm{~Pb}$ and ${ }^{208} \mathrm{~Pb} /{ }^{204} \mathrm{~Pb}$ than MORB for a given ${ }^{206} \mathrm{~Pb} / 204 \mathrm{~Pb}$. We would emphasize, however, that some of these data have a relatively high error associated with them because of the small amount of $\mathrm{Pb}$ being analyzed (e.g., the orthopyroxene from Section 22R-7). In addition, we have yet to determine the concentrations of $\mathrm{Sr}, \mathrm{Nd}$, and $\mathrm{Pb}$ in the various mineral separates. Therefore, we are unable to make blank corrections at this time. These analyses are currently in progress. Similarly, we are attempting to duplicate the analyses for the harzburgite pyroxenes in Sample 22R-7, 45-49 cm. Unfortunately, we are unable to duplicate the analyses for the websterite nodules because all available material was consumed in completing the initial analyses.

\section{DISCUSSION}

\section{Alteration-A Role For Sediment?}

Peridotites from Site 920 have $\mathrm{Sr}$ - and $\mathrm{Pb}$-isotope compositions significantly more radiogenic than normal unaltered MORB. These

Table 3. $\mathrm{Sr}$, $\mathrm{Nd}$, and $\mathrm{Pb}$ isotopes of websterite and harzburgite pyroxenes, vein amphibole, serpentine, and leachates.

\begin{tabular}{|c|c|c|c|c|c|c|c|c|c|c|c|}
\hline Sample name & Sample type & ${ }^{87} \mathrm{Sr} /{ }^{86} \mathrm{Sr}$ & s.e. & ${ }^{143} \mathrm{Nd} /{ }^{144} \mathrm{Nd}$ & s.e. & ${ }^{206} \mathrm{~Pb} /{ }^{204} \mathrm{~Pb}$ & s.e. & ${ }^{207} \mathrm{~Pb} /{ }^{204} \mathrm{~Pb}$ & s.e. & ${ }^{208} \mathrm{~Pb} /{ }^{204} \mathrm{~Pb}$ & s.e. \\
\hline $\begin{array}{l}153-920 \mathrm{D}- \\
12 \mathrm{R}-1,128-134 \\
12 \mathrm{R}-1,128-134 \\
12 \mathrm{R}-1,128-134\end{array}$ & $\begin{array}{l}\text { Hornblende } \\
\text { Tremolite } \\
\text { Hornblende leachate }\end{array}$ & $\begin{array}{l}0.703046 \\
0.705437\end{array}$ & $\begin{array}{l}12 \\
13\end{array}$ & $\begin{array}{l}0.513230 \\
0.513204 \\
0.513203\end{array}$ & $\begin{array}{l}3 \\
5 \\
4\end{array}$ & $\begin{array}{l}18.275 \\
18.374 \\
18.066\end{array}$ & $\begin{array}{r}11 \\
10 \\
8\end{array}$ & $\begin{array}{l}15.586 \\
15.620 \\
15.594\end{array}$ & $\begin{array}{r}10 \\
9 \\
7\end{array}$ & $\begin{array}{l}37.877 \\
38.057 \\
37.832\end{array}$ & $\begin{array}{l}25 \\
21 \\
17\end{array}$ \\
\hline $\begin{array}{l}13 R-2,65-68 \\
13 R-2,65-68 \\
13 R-2,65-68 \\
13 R-2,65-68\end{array}$ & $\begin{array}{l}\text { Pyroxene w/ inclusions } \\
\text { Pyroxene w/o inclusions } \\
\text { Pyx w/ inclusions leachate } \\
\text { Pyroxene leachate }\end{array}$ & $\begin{array}{l}0.705526 \\
0.704266 \\
0.708942\end{array}$ & $\begin{array}{l}64 \\
58 \\
17\end{array}$ & $\begin{array}{l}0.513303 \\
0.513268 \\
0.511613\end{array}$ & $\begin{array}{r}10 \\
28 \\
162\end{array}$ & $\begin{array}{l}18.400 \\
18.444 \\
18.571 \\
18.381\end{array}$ & $\begin{array}{r}42 \\
25 \\
3 \\
3\end{array}$ & $\begin{array}{l}15.713 \\
15.696 \\
15.645 \\
15.630\end{array}$ & $\begin{array}{r}36 \\
21 \\
3 \\
3\end{array}$ & $\begin{array}{l}38.155 \\
38.305 \\
38.246 \\
38.103\end{array}$ & $\begin{array}{r}87 \\
50 \\
7 \\
7\end{array}$ \\
\hline $\begin{array}{l}15 R-3,18-21 \\
15 R-3,18-21 \\
15 R-3,18-21\end{array}$ & $\begin{array}{l}\text { Pyroxene } \\
\text { Pyroxene leachate } \\
\text { Serpentine }\end{array}$ & $\begin{array}{l}0.704412 \\
0.706826\end{array}$ & 32 & $\begin{array}{l}0.513285 \\
0.513231\end{array}$ & 7 & $\begin{array}{l}18.553 \\
18.569 \\
18.385\end{array}$ & $\begin{array}{r}21 \\
4 \\
74\end{array}$ & $\begin{array}{l}15.690 \\
15.644 \\
15.560\end{array}$ & $\begin{array}{r}17 \\
3 \\
61\end{array}$ & $\begin{array}{l}38.265 \\
38.223 \\
38.007\end{array}$ & $\begin{array}{r}41 \\
7 \\
149\end{array}$ \\
\hline $\begin{array}{l}22 \mathrm{R}-7,45-49 \\
22 \mathrm{R}-7,45-49 \\
22 \mathrm{R}-7,45-49 \\
22 \mathrm{R}-7,45-49 \\
22 \mathrm{R}-7,45-49\end{array}$ & $\begin{array}{l}\text { Orthopyroxene } \\
\text { Orthopyroxene } \\
\text { Clinopyroxene } \\
\text { Orthopyroxene leachate } \\
\text { Clinopyroxene leachate }\end{array}$ & $\begin{array}{l}0.704854 \\
0.704847 \\
0.702886 \\
0.708492\end{array}$ & $\begin{array}{r}14 \\
29 \\
7 \\
11\end{array}$ & 0.513149 & $\begin{array}{r}8 \\
160\end{array}$ & $\begin{array}{l}18.734 \\
18.504 \\
17.896 \\
17.839\end{array}$ & $\begin{array}{r}19 \\
3 \\
7\end{array}$ & $\begin{array}{l}15.649 \\
15.600 \\
15.610\end{array}$ & $\begin{array}{r}15 \\
3 \\
6\end{array}$ & $\begin{array}{l}38.425 \\
37.741 \\
37.723\end{array}$ & $\begin{array}{r}39 \\
7 \\
15\end{array}$ \\
\hline
\end{tabular}

Note: All samples were leached in 6-M HCI except tremolite from Sample 153-920D-12R-1, 128-134 cm, and serpentine from Sample 15R-3, 18-21 cm. Errors quoted are 1 6 standard error (s.e.). Pyx = pyroxene. 


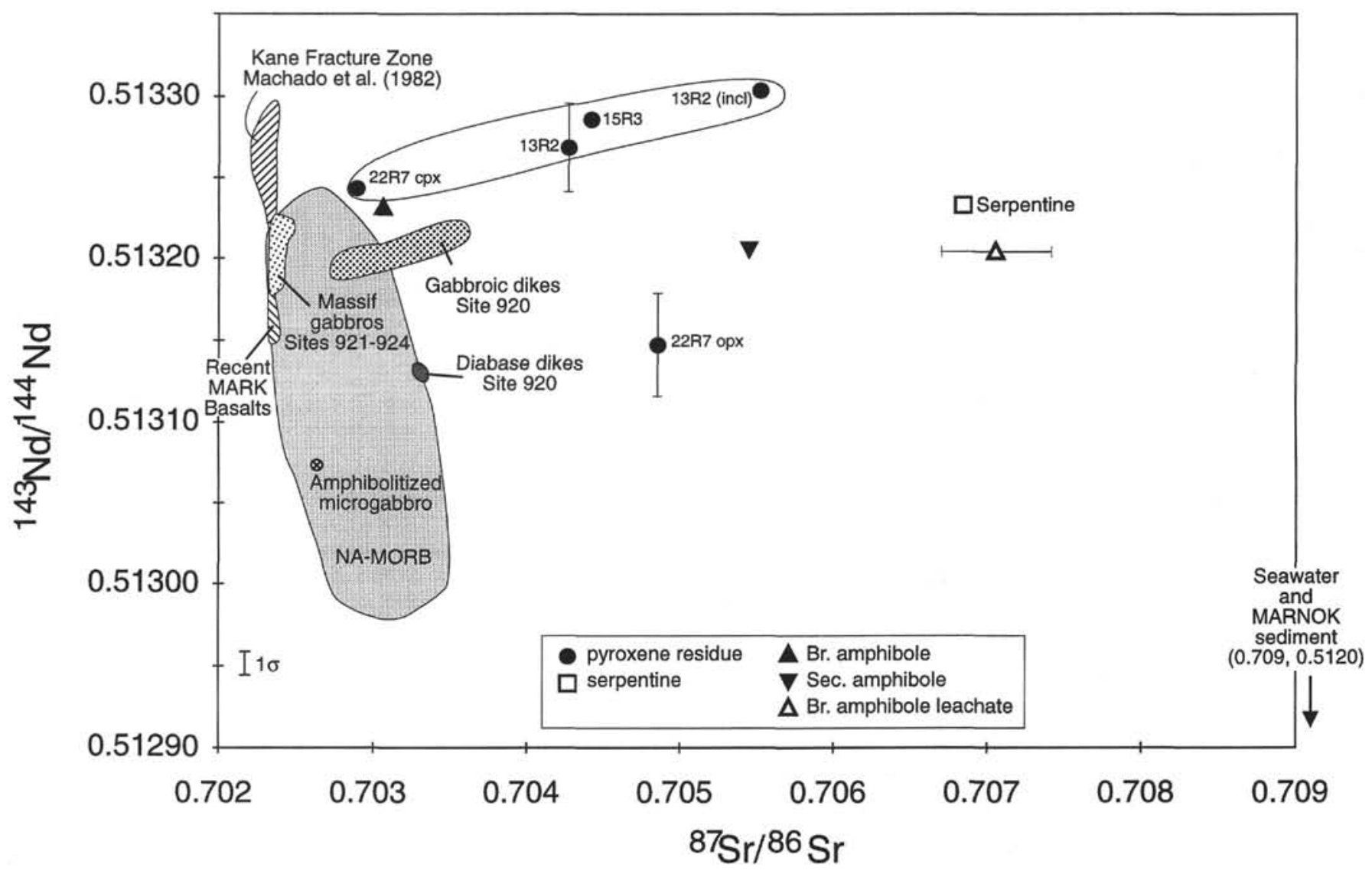

Figure 4. Plot of ${ }^{87} \mathrm{Sr} /{ }^{86} \mathrm{Sr}$ vs. ${ }^{143} \mathrm{Nd} /{ }^{144} \mathrm{Nd}$ for Leg 153 peridotites. Shown for comparison are fields for massif gabbros from Sites 920 to 924 and gabbroic dikes from Site 920 (Kempton and Hunter, this volume), diabase dikes from Sites 920 and 921 (Kempton and Casey, this volume), amphibolitized microgabbro from Site 920, recent MARK basalt glasses from the neovolcanic zone (Kempton and Hunter, this volume), and North Atlantic N-MORB (indicated as NA-MORB on figure). Data for NA-MORB field from Cohen et al. (1980), Cohen and O'Nions (1982), Dosso et al. (1991, 1993), Frey et al. (1993), Ito et al. (1987), and White and Hofmann (1982). Data from Machado et al. (1982) are shown separately; these data have been normalized using Machado's published value for BCR $(0.512679 \pm 20)$ to make them consistent with NIGL measured value for this rock standard $(0.512602)$. Data for MARNOK sediment from P.D. Kempton (unpubl, data). The $1 \sigma$ error bar for ${ }^{143} \mathrm{Nd} /{ }^{144} \mathrm{Nd}$ shown in the lower left corner is based on replicate analyses of $\mathrm{J} \& \mathrm{M}$ Nd standard solution; $1 \sigma$ error for ${ }^{87} \mathrm{Sr} /$ ${ }^{86} \mathrm{Sr}$ is within the size of the symbols for most samples. Where the $1 \sigma$ error exceeds these ranges, the errors are as shown for the individual samples. Br. $=$ brown, Sec. $=$ secondary, $\mathrm{cpx}=$ clinopyroxene, opx $=$ orthopyroxene, incl $=$ inclusion.

values are a clear indication that the $\mathrm{Sr}$ and $\mathrm{Pb}$ isotopes have been disturbed by hydrothermal alteration and serpentinization. Until recently, the isotopic composition of the fluids involved in these processes has been assumed to be that of average seawater or some mixture between seawater and oceanic basalts. However, Snow et al. (1994a) have shown that there can be a significant component of ${ }^{87} \mathrm{Sr}$ derived from continental crust in oceanic sediments, and the same is almost certainly true for $\mathrm{Pb}$. Although the $\mathrm{Sr}$-isotope composition of seawater $(0.7092)$ is well known by direct measurement of seawater samples, the $\mathrm{Pb}$-isotope composition is usually inferred from the compositions of sediments and Mn nodules because of its low concentration in seawater. Based on the results of leaching experiments on Leg 153 gabbros, Kempton and Hunter (this volume) have suggested that the compositions of average seawater and local sediments for the MARK area are not the same, at least with respect to $\mathrm{Pb}$ isotopes. These authors suggest that, for most gabbro samples from Leg 153, the hydrothermal fluids responsible for alteration involved only seawater, but in a few cases local sediments were also involved - the principal consequence being elevated ${ }^{206} \mathrm{~Pb} /{ }^{204} \mathrm{~Pb}$ and ${ }^{208} \mathrm{~Pb} /{ }^{04} \mathrm{~Pb}$. Thus, although hydrothermal fluids in the ocean crust may be dominated by seawater, the $\mathrm{Pb}$-isotope composition of that fluid may locally be more or less radiogenic than average seawater if pelagic sediments are involved.
For Leg 153 peridotites, ${ }^{208} \mathrm{~Pb} /{ }^{204} \mathrm{~Pb}$ vs. ${ }^{206} \mathrm{~Pb} /{ }^{204} \mathrm{~Pb}$ systematics for peridotites show a clear linear trend from the MORB field toward pelagic sediment. Although we have not analyzed a sample of the sediment from the MARK area specifically, we have analyzed pelagic ooze and a manganese encrustation on basalt from the MARNOK area immediately north of the Kane Fracture Zone. The MARNOK sediment data are clearly consistent with the hypothesis that sediments are involved in the alteration. ${ }^{207} \mathrm{~Pb} /{ }^{204} \mathrm{~Pb}$ vs. ${ }^{206} \mathrm{~Pb} /{ }^{204} \mathrm{~Pb}$ systematics are less convincing because most of the peridotites have higher ${ }^{207} \mathrm{~Pb} /{ }^{204} \mathrm{~Pb}$ than the analyzed sediments. However, given the large error on the measured ${ }^{207} \mathrm{~Pb} / 204 \mathrm{~Pb}$ ratios, we would argue that the sediment hypothesis cannot be ruled out on the basis of the ${ }^{207} \mathrm{~Pb} /$ ${ }^{204} \mathrm{~Pb}$ data. Indeed, the fact that serpentine separated from Sample $15 \mathrm{R}-3,18-21 \mathrm{~cm}$, has near-seawater values for $\mathrm{Sr}$ isotopes, but lower ${ }^{208} \mathrm{~Pb} /{ }^{204} \mathrm{~Pb}$ than the leached pyroxenes, suggests that (1) seawater, on average, has lower ${ }^{208} \mathrm{~Pb} /{ }^{204} \mathrm{~Pb}$ than the local sediment, and (2) alteration of the peridotites involved a range of fluid compositions in which the proportion of seawater to sediment $\mathrm{Pb}$ varied.

The trend toward low ${ }^{206} \mathrm{~Pb} /{ }^{204} \mathrm{~Pb}$ for the leachates from harzburgite Sample 22R-7, 45-49 cm, is enigmatic and we have no explanation for it at this time, particularly because the leachates from the nodular websterites lie within the main trend of data. Similar unradiogenic values were found in leachates from most Leg 153 gabbros 

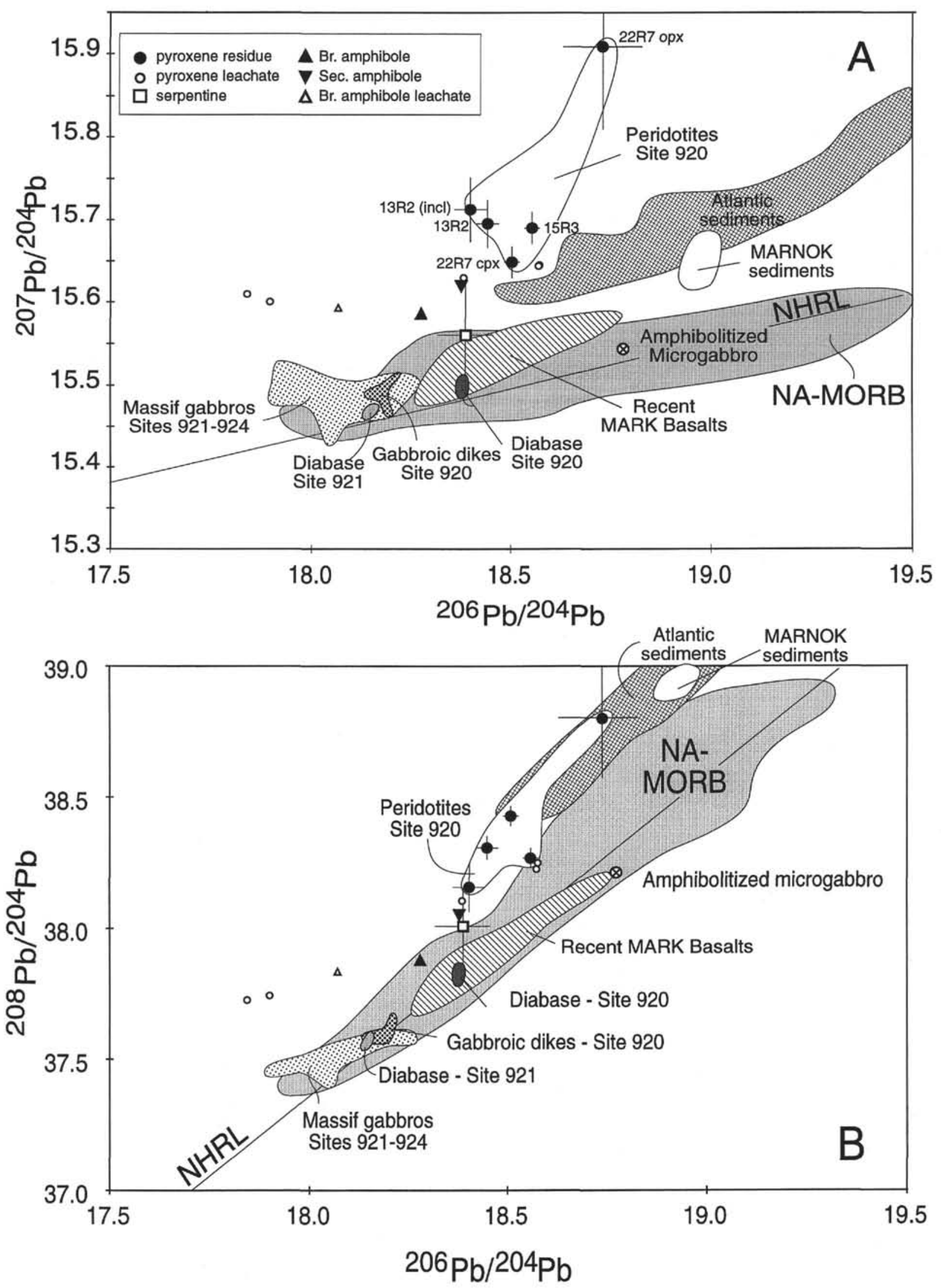

Figure 5. Plot of ${ }^{206} \mathrm{~Pb} /{ }^{204} \mathrm{~Pb}$ vs. $(\mathbf{A}){ }^{207} \mathrm{~Pb} /{ }^{204} \mathrm{~Pb}$ and $(\mathbf{B}){ }^{208} \mathrm{~Pb} /{ }^{204} \mathrm{~Pb}$. Data for North Atlantic N-MORB (NA-MORB) field are from Dupré and Allègre (1980), Dupré et al. (1981), Hamelin et al. (1984), Sun (1980), and sources listed in Figure 4. Data for Atlantic sediment field from Ben Othman et al. (1989), Sun (1980), and White et al. (1985). Abbreviations as in Figure 4. 
(Kempton and Hunter, this volume). Kempton et al. (1993) also found unradiogenic compositions for leachates from basalt glass dredged from MARNOK, and suggested that this component may be caused by contamination with anthropogenic $\mathrm{Pb}$. We are currently investigating this possibility along with analytical alternatives.

\section{Origin of Nodular Websterites at Site 920}

One of the original objectives of this study was to determine the relationship between the nodular websterites and the predominantly harzburgitic core at Site 920. Clearly the high modal proportion of pyroxenes observed in the websterite nodules is in marked contrast to the average state of depletion of the rest of the core. Major-element mineral data indicate that the primary silicate phases in the nodular websterites are similar to average Site 920 peridotite in major components (i.e., $\mathrm{Ca}, \mathrm{Mg}$, and $\mathrm{Fe}$ ), but differ in the concentrations of some minor elements. In particular, concentrations of $\mathrm{Cr}_{2} \mathrm{O}_{3}$ at a given $\mathrm{Al}_{2} \mathrm{O}_{3}$ are higher in websterite pyroxenes than they are in average Site 920 peridotite (Fig. 2). Concentrations of $\mathrm{Fe}$ and $\mathrm{Ti}$ are also higher than the average in pyroxenes from Sample $15 \mathrm{R}-3,18-21 \mathrm{~cm}(\mathrm{Ta}-$ ble 2).

One obvious possibility is that these inclusions are remnants of veins. Dick et al. (1984) interpreted abyssal websterites from the Kane and Islas Orcadas Fracture Zones as evidence for "in situ" crystallization of partial melt trapped in peridotite matrix. The Leg 153 core provides ample evidence for melt infiltration processes in mantle peridotite, ranging from $\mathrm{mm}$-size veinlets of $\mathrm{Mg}$-rich clinopyroxene ( \pm spinel \pm plagioclase) to $\mathrm{cm}$ - and $\mathrm{m}$-size dikes of gabbro and diabase, respectively. Of these, the $\mathrm{Mg}$-rich clinopyroxene veinlets are the most similar to the websterites. However, the precise nature of the relationship between these and the websterites is uncertain. Clearly, they differ in mineralogy in that the nodular websterites contain high modal proportions of orthopyroxene as well as clinopyroxene, whereas the veinlets are composed predominantly of clinopyroxene \pm spinel or plagioclase. The presence of orthopyroxene and absence of plagioclase in the websterites suggests a slightly higher pressure origin for the websterites.

One of the more intriguing observations made from the Site 920 core is that cyclic variations in modal mineral proportions occur on a scale of centimeters to tens of meters, and clinopyroxenite and/or gabbroic veins are frequently associated with the most depleted portions of these cyclic variations. This has been interpreted as evidence for interaction between basaltic melts and peridotite wallrock in the Site 920 core (Shipboard Scientific Party, 1995). Therefore, it might be argued that if the websterites are remnants of veins, there should be a depletion zone adjacent to them. In Section 15R-3, the modal proportion of pyroxene is lower in the harzburgite, relative to the rest of the section, within $20 \mathrm{~cm}$ of the websterite. However, the presence of a clinopyroxenite veinlet adjacent to the websterite makes it difficult to establish whether or not the depletion in this interval is related to either of the veins. Furthermore, in a detailed study of websterite veins in alpine peridotites, Rivalenti et al. (1995) identified two types of peridotite to websterite transition. In one type, depletion of the peridotite increases and clinopyroxene fertility decreases towards the contact; $\mathrm{Al}$ is lower and $\mathrm{Cr}$ higher in the websterite clinopyroxene with respect to the adjacent peridotite. In the second type of transition, as the contact is approached, there is an increase in modal clinopyroxene. The wallrock depletion in the first transition type is interpreted to be caused by melt extraction induced by intrusion of melts derived from deeper mantle. The second transition type is interpreted in terms of melt infiltration and re-equilibration of the melt with the peridotite matrix. Therefore, depletion adjacent to the websterite is not a prerequisite for a vein origin.

Compositional similarities between the nodular websterites and the clinopyroxenite veinlets, nevertheless, support a vein origin for the websterites. Cannat, Chatin, et al. (this volume) found that the compositions of pyroxenes in the veinlets largely overlap those of re- sidual clinopyroxene in the harzburgites, except that clinopyroxene in thicker veins has slightly higher $\mathrm{Fe}$ and $\mathrm{Na}$ contents. Niida (this volume) also notes elevated $\mathrm{Fe}$ in veinlet clinopyroxene as well as elevated $\mathrm{Ti}$ and depletions in $\mathrm{Mg}$. These compositional characteristics are similar to those of the Site 920 websterites (Table 2). Cannat et al. (1994) also suggested that the thin clinopyroxene veinlets are evidence for trails of melt infiltration that occurred in the peridotite at high temperatures, possibly close to the solidus, which in turn implies that this event took place in the asthenospheric mantle. If so, given the structural and textural similarities between the websterite and harzburgite minerals, the websterites must also be asthenospheric in origin, possibly as a result of decompression melting in an upwelling diapir.

Compositional characteristics of residual peridotites associated with increasing partial fusion (in the pressure range of spinel peridotite facies) include the following: an increase of $\mathrm{Mg \# ,} \mathrm{a} \mathrm{decrease} \mathrm{of}$ $\mathrm{wt} \%$ alumina in orthopyroxene, and a decrease of $\mathrm{Al}$ along with an increase of $\mathrm{Cr}$ in spinel (Michael and Bonatti, 1985). Conversely, if the websterites and clinopyroxenites represent the complementary partial melt to the depleted peridotite in which they are enclosed, they should be more $\mathrm{Fe}, \mathrm{Ti}, \mathrm{Na}$, and $\mathrm{Al}$ rich than the residua.

However, Niida (this volume) notes depletions in $\mathrm{Al}$ and $\mathrm{Cr}$ in vein clinopyroxene relative to residual clinopyroxene. Although this relationship is analogous to that of the Site 670 websterite and associated harzburgites, it contrasts with the Site 920 websterites which have higher $\mathrm{Cr}$ and relatively high $\mathrm{Al}$ contents (Fig. 2). Similarly, the Tereveka clinopyroxenites have both higher and lower $\mathrm{Cr}$ and $\mathrm{Al}$ than the Tereveka harzburgites. Rivalenti et al. (1995) observed higher $\mathrm{Cr}$ and lower $\mathrm{Al}$ in websterite pyroxenes in alpine peridotites relative to the peridotite away from the veins, but Kempton $(1984,1987)$ found the reverse situation for Type I/Type I composite xenoliths. In addition, olivines in the websterites and clinopyroxenites have high $\mathrm{Ni}$ contents indistinguishable from the surrounding harzburgites (Table 2; Fuji, 1990; Juteau et al., 1990; Constantin et al., 1995). It therefore seems unlikely that these assemblages represent the direct crystallization product of trapped liquid extracted from surrounding peridotite during partial melting.

Many workers now interpret websterites and clinopyroxenite layers and clusters to be crystal cumulates derived by the interaction of partial melt with host peridotite rather than representing the actual partial melt itself (Sinigoi et al., 1983; Frey, 1984; Spray, 1989; Shervais and Mukasa, 1991; Rivalenti et al., 1995). Some of the compositional complexities observed may thus be a function of varying proportions of cumulus and/or residual minerals relative to trapped melt. Furthermore, based on studies of alpine peridotite massifs, Scribano (1987) suggests that $\mathrm{Cr}$ diopside websterites form at the start of the fractionation path of such melts and that more Al-Ti-Fe augite websterites occur at an evolved stage. This agrees with the observation that the websterites, both from Site 670 and Site 920, are plastically deformed, similar to the surrounding harzburgite. However, the high $\mathrm{Nd}$-isotope ratios of the websterite pyroxenes indicate high time-integrated $\mathrm{Sm} / \mathrm{Nd}$ ratios (i.e., greater depletion of light relative to heavy rare-earth elements), suggesting that they may be more depleted in trace-element terms than the surrounding peridotite. This is inconsistent with the pyroxene-rich modes of the websterites and suggests that the concentration of pyroxene in the veins is a fairly recent process. Trace-element analyses in progress should help resolve this problem and give us a better understanding of the mechanisms of melt migration represented by the websterites.

\section{Relationship Between Leg 153 Peridotites and Magmatic Rocks}

As previously discussed, $\mathrm{Sr}$ - and $\mathrm{Pb}$-isotope systematics of $\mathrm{Leg}$ 153 peridotites have been strongly affected by secondary processes. Even after strong acid leaching, it is not possible to obtain $\mathrm{Sr}$ - or $\mathrm{Pb}$ isotope values that unambiguously reflect the primary composition. 
Instead, all values must be considered maximum estimates of the primary composition. For example, the websterite sample containing inclusions has a higher ${ }^{87} \mathrm{Sr} /{ }^{86} \mathrm{Sr}$ ratio (Fig. 4) than does the cleaner split of the same sample, a result consistent with greater alteration.

In contrast to the $\mathrm{Sr}$ - and $\mathrm{Pb}$-isotope compositions, the rare-earth elements (REE) are significantly less mobile during seawater alteration and/or serpentinization (Humphris and Thompson, 1978). Peridotite analyses by many authors have shown no correlation between increasing degree of serpentinization and REE pattern shape or REE concentrations (Bodinier et al., 1990; Frey et al., 1985; Gruau et al., 1991). However, we observe a significant difference in the Nd-isotope composition between pyroxenes and serpentine separated from the same sample (Fig. 4). Therefore, we have analyzed only clean, hand-picked pyroxenes separated from the peridotites rather than whole-rock samples to identify the primary compositions if possible. We are confident that extrapolation of the pyroxene data to the whole-rock system is justified for the following reasons. For the websterite samples, both clinopyroxene and orthopyroxene are included in the analyzed sample. Thus, less than $15 \%$ of the original mineral assemblage (i.e., the olivine and spinel) is excluded, and the concentration of $\mathrm{Nd}$ in these phases is extremely low. Even for the harzburgites, it is a simple calculation to show that if we assume standard distribution coefficients for REE in mantle minerals (e.g., Keleman et al., 1992), the coexisting olivine, orthopyroxene and spinel contain $<10 \%$ of all the REE, and less than $5 \%$ of the Sm and Nd. Thus, clinopyroxene is by far the main reservoir for the REE in abyssal peridotites. For this reason, its ${ }^{143} \mathrm{Nd} /{ }^{144} \mathrm{Nd}$ is almost certainly representative of the original whole-rock composition, and given the degree of serpentinization of the orthopyroxene and olivine in most samples, it is clearly the best estimate available.

The pyroxene data from the websterites and the clinopyroxene from harzburgite Sample 22R-7, 45-49 cm, are consistent with this assumption. The relatively high $\mathrm{Nd}$-isotope values of these samples are unlikely to be the product of alteration or serpentinization because seawater and local sediments have significantly lower ${ }^{143} \mathrm{Nd} /{ }^{144} \mathrm{Nd}$ values. Serpentinization would therefore only serve to lower the Ndisotope ratios of the peridotites. This is consistent with the lower ${ }^{143} \mathrm{Nd} /{ }^{144} \mathrm{Nd}$ value of the serpentine separated from Sample 15R-3, $18-21 \mathrm{~cm}$. One clear exception is the orthopyroxene from harzburgite Sample 22R-7, $45-49 \mathrm{~cm}$. This sample has a low ${ }^{143} \mathrm{Nd} /{ }^{144} \mathrm{Nd}$ value, consistent with partial exchange with seawater and/or sediment. This low value contrasts with the composition of the coexisting clinopyroxene, but it is not really surprising in that the $\mathrm{Nd}$ concentration in orthopyroxene is significantly lower than that in clinopyroxene and thus more easily affected by alteration. $\mathrm{Pb}$ isotopes suggest that alteration of the orthopyroxene involves pelagic sediment as well as seawater because the $\mathrm{Pb}$-isotope ratios of the serpentine are lower than those of the peridotites, whereas the sediments have higher $\mathrm{Pb}$ isotope ratios.

Based on these data, it is interesting that the peridotite pyroxenes have higher ${ }^{143} \mathrm{Nd} /{ }^{144} \mathrm{Nd}$ than the Leg 153 gabbros (Fig. 4; Kempton and Hunter, this volume). Thus, if the nodular inclusions represent veins, as suggested in the previous section, they clearly did not originate from the same source as that giving rise to either the gabbro veins at Site 920 or the gabbro massif at Sites 921-924. They are even less like the recent basalts from the neovolcanic zone. This indicates that the peridotite pyroxenes analyzed are not representative (at least isotopically) of the source for the magmas which produced the MARK gabbros (Kempton and Hunter, this volume).

Although the Leg 153 peridotites overlap the high Nd-isotope end of the MORB array (Fig. 4), this end of the field is defined by basaltic samples dredged from the Kane Fracture Zone (Machado et al., 1982). Note that these values are higher than any other data reported for the Kane Fracture Zone area. We have analyzed samples of plagiogranite and diabase (P.D. Kempton, unpubl. data) dredged from localities near to those sampled and analyzed by Machado et al. (1982), and these samples yield Nd-isotope values identical to those of Leg 153 gabbros. We therefore suspect that there is an interlaboratory bias and that the Machado et al. (1982) data may need revision to be internally consistent with our own data.

If the Machado data are systematically too high, as suggested by our data for Kane Fracture Zone samples, the Nd values measured for the Leg 153 peridotites are higher than most previously published analyses of North Atlantic MORB. Only two unusual basalts from $17^{\circ} \mathrm{N}$ (Dosso et al., 1993) have higher ${ }^{143} \mathrm{Nd} /{ }^{144} \mathrm{Nd}$ ratios $(0.51335-$ 0.51336 ). The Site 920 peridotites also have higher Nd-isotope ratios than any analyzed abyssal peridotites known to the authors.

How do we explain the apparent incongruity that the Site 920 peridotites have more depleted Nd-isotope ratios than the magmatic rocks from the same area? One possibility proposed by Snow et al. (1994b) is that enriched veins in the mantle source have a lower melting point and are sampled by the first fractions of melting. This results in relatively enriched melts in the early fractions, followed by more depleted melts. Residues of melting that have lost their vein components would then have more depleted isotopic compositions than basalts derived from both early and later melting. However, the highest Nd-isotope values at Site 920 are found in assemblages interpreted as veins rather than the residues from partial melting, and both websterites have higher Nd-isotope values than pyroxenes from the harzburgite in Section 22R-7. Admittedly, it is unclear whether the nodular websterites are distinct from the analyzed harzburgite, because (1) the compositional range of the Site 920 peridotites has not been established on the basis of the one harzburgite sample analyzed here, and (2) one of the nodular inclusions overlaps the clinopyroxene from Sample 22R-7, 45-49 cm, within analytical error. Nevertheless, Spray (1989) argues that veins devoid of hydrous phases are unlikely to be parental to MORBs. If this is correct, the websterite veins may not be representative of types of veins that would contribute to the early melting events proposed by Snow (1994b). More data will need to be collected on Site 920 peridotites to establish the range of compositions before further interpretations are possible.

\section{CONCLUSIONS}

1. The pyroxenes from the two websterites and clinopyroxene from one harzburgite sample analyzed from Leg 153 peridotites are isotopically distinct from all magmatic rocks in the MARK area (i.e., gabbros, diabase dikes, and recent basalts). They are, therefore, not representative of the mantle source of these magmatic rocks, at least with respect to its isotopic composition. The $\mathrm{Nd}$-isotope ratios of the peridotites are higher (i.e., more depleted) than most N-MORB from the North Atlantic and higher than any measured abyssal peridotite known to the authors.

2. High alumina, iron, and titanium contents in the websterite pyroxenes suggest a vein origin, possibly as a result of decompression melting in an upwelling diapir. These veins preceded the more numerous clinopyroxenite veinlets observed throughout the Site 920 core and probably formed in the asthenosphere.

3. $\mathrm{Sr}$ and $\mathrm{Pb}$ isotopes provide evidence for seawater interaction and ${ }^{208} \mathrm{~Pb} /{ }^{204} \mathrm{~Pb}$ ratios suggest a component of pelagic sediment. Even after extensive leaching, it is not possible to obtain $\mathrm{Sr}$ - or $\mathrm{Pb}$-isotope ratios that unambiguously reflect the primary composition.

\section{ACKNOWLEDGMENTS}

We would like to thank Shoji Arai, Paul Robinson, and Jay Miller for constructive reviews. Support for this work was provided by NERC grant GST/02/990. This paper represents NIGL Publication Series \#161. 


\section{REFERENCES}

Ben Othman, D., White, W.M., and Patchett, J., 1989. The geochemistry of marine sediments, island arc magma genesis and crust-mantle recycling. Earth Planet. Sci. Lett., 94:1-21.

Bodinier, J.L., Vasseur, G., Vernieres, J., Dupuy, C., and Fabries, J., 1990. Mechanisms of mantle metasomatism: geochemical evidence from the Lherz Orogenic Peridotite. J. Petrol., 31:597-628.

Cannat, M., Whitechurch, H., and Leg 153 Scientific Party, 1994. Chemical diversity and relative timing of melt circulation in Mid-Atlantic Ridge serpentinized peridotites drilled at ODP Site 920. Eos, 75:626.

Cohen, R.S., Evensen, N.M., Hamilton, P.J., and O'Nions, R.K., 1980. U-Pb, $\mathrm{Sm}-\mathrm{Nd}$, and $\mathrm{Rb}-\mathrm{Sr}$ systematics of mid-ocean ridge basalt glasses. Nature, 283:149-153.

Cohen, R.S., and O'Nions, R.K., 1982. The lead, neodynium and strontium isotopic structure of ocean ridge basalts. J. Petrol., 23:299-324.

Constantin, M., Hékinian, R., Ackerman, D., and Stoffers, P., 1995. Mafic and ultramafic intrusions into upper mantle peridotites from fast spreading centers of the Easter Microplate (South East Pacific). In Vissers, R., and Nicolas, A. (Eds.), Mantle and Lower Crust Exposed in Oceanic Ridges and in Ophiolites: Rotterdam (Kluwer), 71-120.

Dick, H.J.B., 1989. Abyssal peridotites, very slow spreading ridges and ocean ridge magmatism. In Saunders, A.D., and Norry, M.J. (Eds.), Mag. matism in the Ocean Basins. Geol. Soc. Spec. Publ. London, 42:71-105.

Dick, H.J.B., and Bullen, T., 1984. Chromian spinel as a petrogenetic indicator in abyssal and alpine-type peridotites and spatially associated lavas. Contrib. Mineral. Petrol., 86:54-76.

Dick, H.J.B., Fisher, R.L., and Bryan, W.B., 1984. Mineralogic variability of the uppermost mantle along mid-ocean ridges. Earth Planet. Sci. Lett., 69:88-106.

Dick, H.J.B., and Sinton, J., 1979. Compositional layering in alpine peridotites: evidence for pressure solution creep in the mantle. J. Geol., 87:403416.

Dosso, L., Bougault, H., and Joron, J.L., 1993. Geochemical morphology of the North Atlantic Ridge, $10^{\circ}-24^{\circ} \mathrm{N}$ : trace element-isotope complementarity. Earth Planet. Sci. Lett., 120:443-462.

Dosso, L., Hanan, B.B., Bougault, H., Schilling, J.G., and Joron, J.L., 1991. $\mathrm{Sr}-\mathrm{Nd}-\mathrm{Pb}$ geochemical morphology between 10 degrees $\mathrm{N}$ and 17 degrees $\mathrm{N}$ on the Mid-Atlantic Ridge - a new MORB isotope signature. Earth Planet. Sci. Lett., 106:29-43.

Dupré, B., and Allègre, C.J., 1980. Pb-Sr-Nd isotopic correlation and the chemistry of the North Atlantic mantle. Nature, 286:17-22.

Dupré, B., Lambret, B., Rousseau, D., and Allègre, C.J., 1981. Limitations of the scale of mantle heterogeneities under ocean ridges. Nature, 294:552554.

Frey, F.A., 1984. Rare earth element abundances in upper mantle rocks. In Henderson, P. (Ed.), Rare Earth Element Geochemistry: Amsterdam (Elsevier), 153-203.

Frey, F.A., and Prinz, M., 1978. Ultramafic inclusions from San Carlos, Arizona: petrologic and geochemical data bearing on their petrogenesis. Earth Planet. Sci. Lett., 38:129-176.

Frey, F.A., Suen, C.J., and Stockman, H.W., 1985. The Ronda high temperature peridotite: geochemistry and petrogenesis. Geochim. Cosmochim. Acta, 49:2469-2491.

Frey, F.A., Walker, N., Stakes, D., Hart, S.R., and Nielsen, R., 1993. Geochemical characteristics of basaltic glasses from the AMAR and FAMOUS axial valleys, Mid-Atlantic Ridge $\left(36^{\circ}-37^{\circ} \mathrm{N}\right)$ : petrogenetic implications. Earth Planet. Sci. Lett., 115:117-136.

Fujii, T., 1990. Petrology of peridotites from Hole 670A, Leg 109. In Detrick, R., Honnorez, J., Bryan, W.B., Juteau, T., et al., Proc. ODP, Sci. Results, 107: College Station, TX (Ocean Drilling Program), 19-25.

Gruau, G., Lecuyer, C., Bernard-Griffiths, J., and Morin, J., 1991. Origin and petrogenesis of the Trinity Ophiolite Complex (California): new constraints from REE and Nd isotope data. In Menzies, M.A., Dupuy, C., and Nicholas, A. (Eds.), Orogenic Lherzolites and Mantle Processes. J. Petrol. Spec. Issue, 229-242.

Hamelin, B., Dupré, B., and Allègre, C.J., 1984. Lead-strontium isotopic variations along the East Pacific Rise and the Mid-Atlantic Ridge: a comparative study. Earth Planet. Sci. Lett., 67:340-350.

Hébert, R., Adamson, A.C., and Komor, S.C., 1990. Metamorphic petrology of ODP Leg 109, Hole 670A serpentinized peridotites: serpentinization processes at a slow spreading ridge environment. In Detrick, R., Honnorez, J., Bryan, W.B., Juteau, T., et al., Proc. ODP, Sci. Results, 106/ 109: College Station, TX (Ocean Drilling Program), 103-115.
Hess, P.C., 1992. Phase equilibria constraints on the origin of ocean floor basalts. In Phipps Morgan, J., Blackman, D.K., and Sinton, J.M. (Eds.), Mantle Flow and Melt Generation at Mid-Ocean Ridges. Geophys. Monogr., Am. Geophys. Union, 71:67-102.

Humphris, S.E., and Thompson, G., 1978. Trace element mobility during hydrothermal alteration of oceanic basalts. Geochim. Cosmochim. Acta, 42:127-136.

Irving, A.J., 1980. Petrology and geochemistry of composite ultramafic xenoliths in alkalic basalts and implications for magmatic processes within the mantle. Am. J. Sci., 280-A:389-426.

Ito, E., White, W.M., and Göpen, C., 1987. The O, Sr, Nd, and Pb isotope geochemistry of MORB. Chem. Geol., 62:157-176.

Juteau, T., Berger, E., and Cannat, M., 1990. Serpentinized, residual mantle peridotites from the M.A.R. median valley, ODP Hole $670 \mathrm{~A}\left(21^{\circ} 10^{\prime} \mathrm{N}\right.$, $45^{\circ} 02^{\prime} \mathrm{W}$, Leg 109): primary mineralogy and geothermometry. In Detrick, R., Honnorez, J., Bryan, W.B., Juteau, T., et al., Proc. ODP, Sci. Results, 106/109: College Station, TX (Ocean Drilling Program), 27-45.

Keleman, P.B., Dick, H.J.B., and Quick, J.E., 1992. Formation of harzburgite by pervasive melt/rock reaction in the upper mantle. Nature, 358:635641.

Kempton, P.D., 1984. I. Alkalic basalts from the Geronimo Volcanic Field: petrologic and geochemical data bearing on their petrogenesis. II. Petrography, petrology and geochemistry of xenoliths and megacrysts from the Geronimo Volcanic Field, Southeastern Arizona. III. An interpretation of contrasting nucleation and growth histories from the petrographic analysis of pillow and dike chilled margins, Hole 504B, DSDP Leg 83 [Ph.D. dissert.] Southern Methodist Univ., Dallas, TX

Kempton, P.D., 1987. Mineralogic and geochemical evidence for differing stiles of metasomatism in spinel lherzolite xenoliths: enriched mantle source regions of basalts. In Menzies, M.A., and Hawkesworth, C.J. (Eds.), Mantle Metasomatism: London (Academic Press), 45-89.

Kempton, P.D., Lawson, N.K., Pearce, J.A., and Browning, P., 1993. Isotopic and chemical variations along the Mid-Atlantic Ridge north of the Kane Fracture Zone [paper presented at IAVCEI, Canberra, Australia]: Ancient Volcanism and Modern Analogues, 57. (Abstract)

Klein, E.M., and Langmuir, C.H., 1987. Global correlations of ocean ridge basalt chemistry with axial depth and crustal thickness. J. Geophys. Res., 92:8089-8115.

Komor, S.C., Grove, T.L., and Hébert, R., 1990. Abyssal peridotites from ODP Hole $670 \mathrm{~A}\left(21^{\circ} 10^{\prime} \mathrm{N}, 45^{\circ} 02^{\prime} \mathrm{W}\right)$ : residues of mantle melting exposed by non-constructive axial divergence. In Detrick, R., Honnorez, J., Bryan, W.B., Juteau, T., et al., Proc. ODP, Sci. Results, 106/109: College Station, TX (Ocean Drilling Program), 85-101.

Langmuir, C.H., Klein, E., and Plank, T., 1992. Petrological systematics of mid-ocean ridge basalts: constraints on melt generation beneath ocean ridges. In Morgan, J., Blackman, D., Sinton, J. (Eds.), Mantle Flow and Melt Generation at Mid-Ocean Ridges. Geophys. Monogr., Am. Geophys. Union, 71:183-277.

Machado, N., Ludden, J.N., Brooks, C., and Thompson, G., 1982. Fine scale isotopic heterogeneity in the sub-Atlantic mantle. Nature, 295:226-229.

MacKenzie, D., 1984. The generation and compaction of partially molten rock. J. Petrol., 25:713-765.

Michael, P.J., and Bonatti, E., 1985. Peridotite composition from the North Atlantic: regional and tectonic variations and implications for partial melting. Earth Planet. Sci. Lett., 73:91-104.

Rivalenti, G., Mazzucchelli, M., Vannucci, R., Hofmann, A., Ottolini, L., Bottazzi, P., and Obermiller, W., 1995. The relationship between websterite and peridotite in the Balmuccia peridotite massif (NW Italy) as revealed by trace element variations in clinopyroxene. Contrib. Mineral. Petrol., 121:275-288.

Salters, V.J.M., and Hart, S.R., 1989. The hafnium paradox and the role of garnet in the source of mid-ocean-ridge basalts. Nature, 342:420-422.

Scribano, V., 1987. Origin of websterite nodules from some alkaline volcanic rocks of Hyblean Plateau (South Eastern Sicily). Period. Mineral., $56: 51-69$.

Shervais, J.W., and Mukasa, S.B., 1991. The Balmuccia orogenic lherzolite massif, Italy. In Menzies, M.A., Dupuy, C., and Nicolas, A. (Eds.), J. Petrol. Spec. Lherzolite Issue, 155-174.

Shibata, T., and Thompson, G., 1986. Peridotites from the Mid-Atlantic Ridge at $43^{\circ} \mathrm{N}$ and their petrogenetic relation to abyssal tholeiites. Contrib. Mineral. Petrol., 93:144-159.

Shipboard Scientific Party, 1995. Site 920. In Cannat, M., Karson, J.A., Miller, D.J., et al., Proc. ODP, Init. Repts., 153: College Station, TX (Ocean Drilling Program), 45-119. 
Sinigoi, S., Comin-Chiaramonti, P., Demarchi, G., and Siena, F., 1983. Differentiation of partial melts in the mantle: evidence from the Balmuccia peridotite, Italy. Contrib. Mineral. Petrol., 82:351-359.

Snow, J.E., Hart, S.R., and Dick, H.J.B., 1994a. Orphan strontium-87 in abyssal peridotites: daddy was a granite. Science, 262:1861-1863.

1994b. Nd and Sr isotope evidence linking mid-ocean-ridge basalts and abyssal peridotites. Nature, 371:57-60.

Spray, J.G., 1989. Upper mantle segregation processes: evidence from alpine-type peridotites. In Saunders, A.D., and Norry, M.J. (Eds.) Mag. matism in the Ocean Basins. Geol. Soc. Spec. Publ. London, 42:29-40.

Sun, S.-S., 1980. Lead isotopic study of young volcanic rocks from midocean ridges, ocean islands and island arcs. Philos. Trans. R. Soc. London A, 297:409-445.
Todt, W., Cliff, R.A., Hanser, A., and Hofmann, A.W., $1984 .{ }^{202} \mathrm{~Pb}$ and ${ }^{205} \mathrm{~Pb}$ double spike for lead isotopic analyses. Terra Cognita, 4:209. (Abstract)

White, W.M., Dupré, B., and Vidal, P., 1985. Isotope and trace element geochemistry of sediments from the Barbados Ridge-Demerara Plain region, Atlantic Ocean. Geochim. Cosmochim. Acta., 49:1875-1886.

White, W.M., and Hofmann, A.W., 1982. Sr and Nd isotope geochemistry of oceanic basalts and mantle evolution. Nature, 296:821-825.

Date of initial receipt: 1 August 1995

Date of acceptance: 22 March 1996

Ms 153SR-022 